\title{
First report of Perkinsus honshuensis in the variegated carpet shell clam Ruditapes variegatus in Korea
}

\author{
Hyun-Sil Kang ${ }^{1}$, Hyun-Sung Yang ${ }^{2}$, Kimberly S. Reece ${ }^{3}$, Hyun-Ki Hong ${ }^{1}$, \\ Kyung-Il Park ${ }^{4}$, Kwang-Sik Choi ${ }^{1, *}$ \\ ${ }^{1}$ School of Marine Biomedical Science (BK21 PLUS), Jeju National University, 102 Jejudaehakno, Jeju 63243, South Korea \\ ${ }^{2}$ Jeju International Marine Science Center for Research and Education, Korea Institute of Ocean Science \& \\ Technology (KIOST), Jeju 63349, South Korea \\ ${ }^{3}$ Virginia Institute of Marine Science, College of William and Mary, PO Box 1346, Gloucester Point, VA 23062-1346, USA \\ ${ }^{4}$ Department of Aquatic Life Medicine, College of Ocean Science and Engineering, Kunsan National University, \\ Gunsan 54150, South Korea
}

\begin{abstract}
The recent discovery of Perkinsus honshuensis, a new Perkinsus species infecting Manila clams Ruditapes philippinarum (Sowerby, 1852), in Japan, suggested that, based on proximity, $P$. honshuensis could also be in Korean waters, where to date, $P$. olseni was believed to be the only Perkinsus species present. Perkinsus sp. infections consistently occurred among Ruditapes variegatus clams on a pebble beach on Jeju Island, off the south coast of Korea. The typical 'signet ring' morphology of the parasite was observed in the connective tissue of the digestive gland, and infection intensity was comparatively low $\left(3.3 \times 10^{3} \pm 1.2 \times 10^{4}\right.$ to $1.3 \times 10^{4} \pm 6.1 \times 10^{4}$ cells $\mathrm{g}^{-1}$ gill weight). Further DNA analyses of internal transcribed spacer (ITS-1, 5.8S and ITS-2) and non-transcribed spacer (NTS) regions of the parasite showed 98.9-99.8 and 98.5-99.5\% similarity to those of $P$. honshuensis from Japan, respectively. Phylogenetic analyses using ITS and NTS sequences indicated that Perkinsus sp. from Jeju formed a highly supported clade with $P$. honshuensis. This is the first report of $P$. honshuensis infections in clams in Korean waters and the first report of $R$. variegatus as a host for that parasite.
\end{abstract}

KEY WORDS: Perkinsus honshuensis - Ruditapes variegatus · Ray's fluid thioglycollate medium • RFTM $\cdot$ Histology $\cdot$ ITS $\cdot$ NTS

\section{INTRODUCTION}

Perkinsosis is a major protozoan disease occurring in a variety of marine molluscs including oysters, clams, scallops, abalones, pearl oysters, cockles and mussels (for review, see Villalba et al. 2004). The recent discovery of Perkinsus honshuensis, a new Perkinsus species infecting Manila clams Ruditapes philippinarum in Japan (Dungan \& Reece 2006), suggested that, based on proximity, $P$. honshuensis could

\footnotetext{
*Corresponding author: skchoi@jejunu.ac.kr
}

also be in Korean waters. Among Perkinsus sp. infecting Korean Manila clams, only P. olseni has been specifically identified to date. A survey carried out along the west, south and east coasts of Korea found Perkinsus sp. infections in clams from natural and commercial clam beds on the west and south coast of the mainland at a wide range of infection prevalences and intensities (Park \& Choi 2001). Park et al. (2005) analyzed internal transcribed spacer (ITS) and non-transcribed spacer (NTS) regions and

๑ The authors 2016. Open Access under Creative Commons by Attribution Licence. Use, distribution and reproduction are unrestricted. Authors and original publication must be credited. 
5.8S ribosomal RNA (rRNA) gene complex sequences of Perkinsus sp. from Manila clams from Korean waters and concluded that the detected parasites were P. olseni reported from Europe, Australia, and Japan. Based on the results of a genus-specific Ray's fluid thioglycollate medium assay (RFTM; Ray 1966), histology, and DNA sequences of the ITS and NTS regions of the ribosomal rRNA gene complex, Park et al. (2006) also reported the clam Protothaca jedoensis as a new host of $P$. olseni. These findings redundantly confirm $P$. olseni as a common or predominant agent of perkinsosis among clams in Korean waters (Park \& Choi 2001, Ngo \& Choi 2004). Infections by 2 different Perkinsus spp. have also been reported from Brazil (mangrove oysters Crassostrea gasar; da Silva et al. 2014), Japan (Manila clams; Dungan \& Reece 2006, Takahashi et al. 2009), and from France (carpet shell clams $R$. decussatus; Arzul et al. 2012). However, in light of the discovery of the new species $P$. honshuensis in Manila clams in nearby Japan (Dungan \& Reece 2006, Takahashi et al. 2009, Umeda \& Yoshinaga 2012), it is important to clarify whether clam populations in Korean waters are indeed infected only by $P$. olseni.

Manila clam health surveys carried out from 2007 to 2011 in Korea revealed Perkinsus-like organisms in the variegated carpet shell $R$. variegatus from Jeju Island off the south coast. Species identity of the Perkinsus-like organism was further investigated using histology and Perkinsus species-specific PCR assays targeting the DNA sequences of ITS and NTS regions of the ribosomal RNA gene complexes. In the present study, we report $R$. variegatus as a new host of $P$. honshuensis.

\section{MATERIALS AND METHODS}

\section{Sampling effort}

Variegated carpet shell clams Ruditapes variegatus (22-31 mm of shell length) were sampled at a pebble beach on Jeju Island $\left(33^{\circ} 29^{\prime} 43^{\prime \prime} \mathrm{N}, 126^{\circ}\right.$ $\left.26^{\prime} 05^{\prime \prime} \mathrm{E}\right)$ in April $(\mathrm{n}=40)$ and November $(\mathrm{n}=40)$ 2007, June $(\mathrm{n}=27) 2009$, and November $(\mathrm{n}=80)$ 2011. Clams obtained in 2007 and 2009 were analyzed using RFTM assays and histology. Of the 80 clams collected in 2011, 30 individuals were analyzed by the RFTM assay and histology. Gill tissue was aseptically excised from the remaining 50 clams and stored at $-70^{\circ} \mathrm{C}$ for subsequent DNA extraction and PCR amplifications of ribosomal RNA gene complex.

\section{RFTM assay}

Gill tissues were inoculated into $5 \mathrm{ml}$ RFTM supplemented with nystatin (200 unit $\mathrm{ml}^{-1}$, Sigma) and chloramphenicol (200 $\mathrm{gg} \mathrm{ml}^{-1}$, Sigma), kept at room temperature for $1 \mathrm{wk}$ in the dark, and digested with $2 \mathrm{M} \mathrm{NaOH}$ according to Choi et al. (1989). After counting the hypnospores using a hemocytometer, the infection intensity was expressed as the number of Perkinsus sp. cells $\mathrm{g}^{-1}$ gill tissue.

\section{Histology}

Clam tissues remaining after processing for the RFTM assay $(n=137)$ were transverse-sectioned and fixed in Davidson's solution. The fixed tissues were dehydrated, embedded in paraffin and sectioned at $5 \mu \mathrm{m}$. The sectioned tissues were stained with hematoxylin and eosin $\mathrm{Y}$ and examined using a light microscope.

\section{PCR assay}

DNA was extracted from a subsample of approximately $25 \mathrm{mg}$ of the frozen gill tissue using a DNeasy Blood and Tissue Kit following the manufacturer's protocol (Qiagen). The ITS and NTS regions of Perkinsus sp. ribosomal DNAs were targeted for PCR amplification from extracted DNAs with primers PKits FW (5'-CTT AGA GGA AGG AGA AGT CGT AAC A-3')/RV (5'-GCT TAL TTA TAT GCT AAA TTC AGC G-3') and PKnts FW (5'AAG TCC TTA GGG TGC TGG CT-3')/RV (5'-ACT ACT GGC AGG ATC AAC CAG GT-3'), respectively, as reported by Park et al. (2005). PCR reactions were carried out in a total volume of $50 \mu \mathrm{l}$ that contained $50 \mathrm{ng}$ of DNA with the Takara Ex Taq polymerase (Takara). The reaction conditions were as follows: denaturation at $95^{\circ} \mathrm{C}$ for $5 \mathrm{~min}$ followed by 30 cycles of $95^{\circ} \mathrm{C}$ for $1 \mathrm{~min}, 58^{\circ} \mathrm{C}$ for $1 \mathrm{~min}$ and $72^{\circ} \mathrm{C}$ for $1 \mathrm{~min}$ with a final elongation of $5 \mathrm{~min}$ at $72^{\circ} \mathrm{C}$. Amplification products were separated on $1.2 \%$ agarose gel and visualized with UV light after ethidium bromide staining.

Amplification products of the expected size (i.e. $\sim 700 \mathrm{bp}$ for ITS and $\sim 1200 \mathrm{bp}$ for NTS) were purified using the AccuPrep gel purification kit (Bioneer) and ligated into the pGEM-T easy vector (Promega). The ligated mixture was used to transform E. coli DH5 $\alpha$ cells, and positive recombinant clones were screened by alpha complementation and colony PCR. Sequences 
of the recombinant clones were determined using the BigDye terminator v3.1 cycle sequencing kit and running the reactions on an ABI PRISM 3730XL analyzer (Applied Biosystems).

NTS region sequences were not available for the monoclonal $P$. honshuensis type strain ATCC PRA-177 from a Japanese Manila clam, which we purchased and propagated in vitro (Dungan \& Reece 2006). Genomic DNA was extracted using a DNeasy Blood and Tissue Kit (Qiagen), and the NTS region of $P$. honshuensis PRA-177 was amplified and sequenced as described above.

Similarities of ITS and NTS sequences of Perkinsus sp. amplified from $R$. variegatus were first compared with those deposited in GenBank using the BLAST program on the NCBI website (http://blast.ncbi.nlm. nih.gov/Blast.cgi). Additional Perkinsus spp. ITS and NTS region sequences were downloaded from GenBank in order to conduct phylogenetic analyses (see Fig. 2 for GenBank accession numbers). The 2 sets of sequences (i.e. the ITS and NTS) were aligned independently using MAFFT vs. 7 online (Katoh \& Standley 2013). Pairwise genetic distances based on uncorrected ' $\mathrm{p}$ ' were calculated in PAUP 4.0a146 (Swofford 2002). Phylogenetic analyses were done using neighbor joining (NJ) and maximum parsimony (MP) methods with 1000 bootstrap based on maximum composite likelihood (ML) model and treebisection-regrafting (TBR) algorithms, respectively, in MEGA (Tamura et al. 2011). Bayesian analyses were conducted using MrBayes v3.25 (Ronquist et al. 2012) under the general time reversible (GTR) model with gamma-distributed rate variation across sites and a proportion of invariable sites.

\section{RESULTS}

\section{RFTM assay}

Enlarged cells with thick cell walls (i.e. hypnospore stage) of Perkinsus sp. were observed in the RFTM assay for some clams sampled in 2007 and 2011 (Table 1). The prevalences and infection intensities of Perkinsus sp. were relatively low during all sampling periods. In 2007, the prevalences varied from 5 (April) to $7.5 \%$ (November), and prevalence was $20 \%$ in 2011. The infection intensities of Perkinsus sp. in Ruditapes variegatus collected during 2007 and 2011 ranged from 0.0 to $3.4 \times 10^{5}$ with an average of $0.0-1.3 \times 10^{4} \pm 6.1 \times 10^{4}$ Perkinsus cell g ${ }^{-1}$ gill weight (Table 1).

\section{Microscopic observation of Perkinsus sp. in $R$. variegatus}

The trophozoites were observed in clams collected in 2011, from hemolymph spaces of the connective tissues surrounding the digestive gland tubules (Fig. 1A) and the intestinal tract (Fig. 1B), varying in diameter from 3.8 to $7.5 \mu \mathrm{m}$. They had a large eccentric vacuole and a nucleus with a prominent nucleolus (Fig. 1A). In addition, clusters of trophozoites were seen either encapsulated or embedded in amorphous eosinophilic material and tissue debris (Fig. 1B).

\section{Molecular identification of Perkinsus sp. infecting $R$. variegatus}

The ITS and NTS regions of genus Perkinsusspecific PCR products amplified from 5 PCR-positive samples among DNAs from 50 clams collected at Oeido, Jeju Island, in 2011 were sequenced and compared to known ITS and NTS sequences reported from other Perkinsus species in GenBank. The NTS and ITS Perkinsus sp. sequences determined for this study were 1148-1150 and 710-711 bp in length, respectively. The sequences reported here were deposited in GenBank under accession numbers KC812378-KC812381 for the ITS region sequences and KC812382-KC812388 for the NTS region sequences. Two NTS sequences from the $P$. honshuensis ATCC PRA-177 were also deposited in GenBank under accession numbers KU064282 and KU064283. 

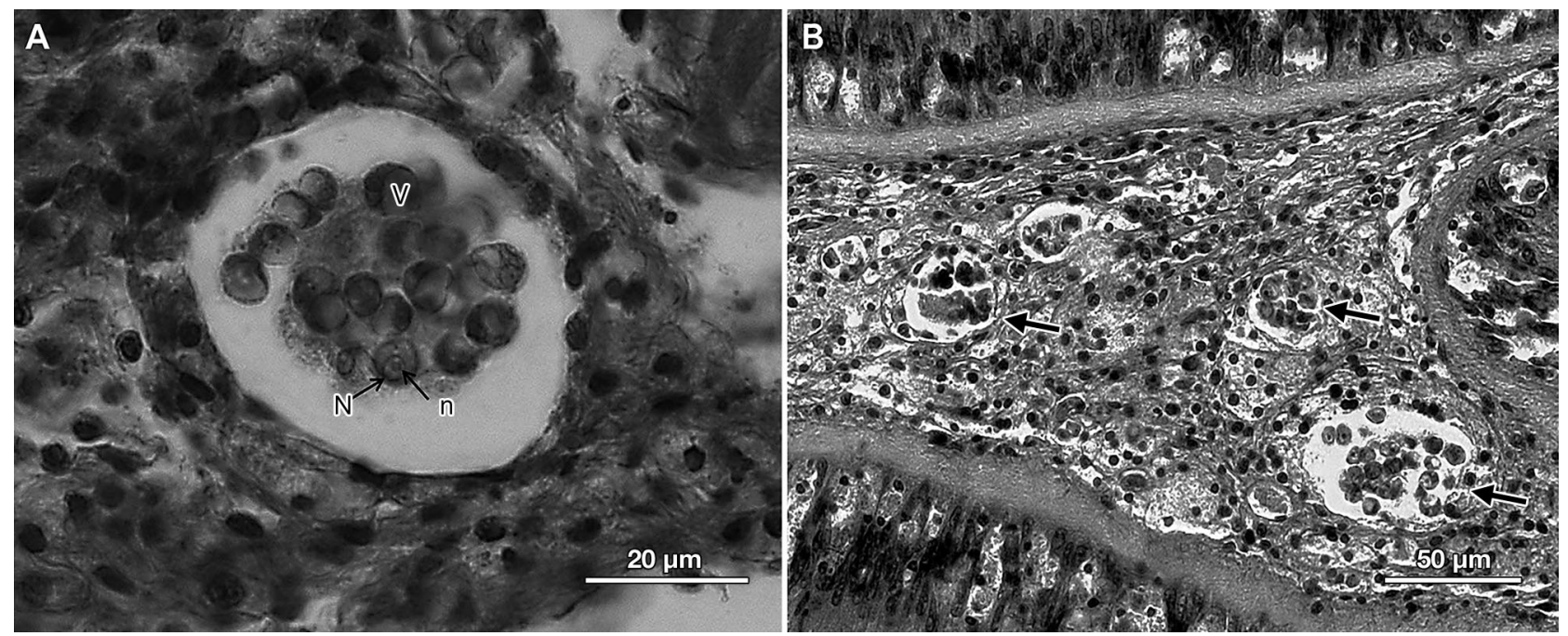

Fig. 1. Microscopic features of Perkinsus sp. infecting Ruditapes variegatus. (A) Cluster of encapsulated Perkinsus sp. trophozoites showing large vacuoles $(\mathrm{V})$, and eccentric nuclei $(\mathrm{N})$ with prominent nucleoli $(\mathrm{n})$ in connective tissue of the digestive gland. (B) Encapsulation (arrows) of Perkinsus sp. cells in connective tissues of the intestinal tract

Pairwise genetic distance analyses showed that the ITS region sequences of the Korean Perkinsus sp. from $R$. variegatus had $98.9-99.8 \%$ similarity (uncorrected ' $\mathrm{p}$ ') to those of the Japanese $P$. honshuensis isolates from $R$. philippinarum. The NTS region sequences obtained from $R$. variegatus Perkinsus sp. showed $98.5-99.5 \%$ similarity to the NTS sequences from the $P$. honshuensis ATCC PRA-177. Similar results were found in pairwise distance analyses of the ITS and NTS region sequences from isolates within each of the other Perkinsus species. Genetic similarity of the ITS region between the $P$. honshuensis/ $R$. variegatus Perkinsus sp. sequences and those from each of the other Perkinsus species ranged from $83.3 \%$ (vs. P. chesapeaki) to $96.5 \%$ (vs. P. mediterraneus). The $P$. honshuensis/R. variegatus Perkinsus sp. NTS region sequences showed much lower genetic similarity to the sequences from other species, ranging from $59.2 \%$ (vs. P. chesapeaki) to $79.3 \%$ (vs. P. olseni).

The NJ, MP and Bayesian trees constructed based on ITS sequences of Perkinsus spp. clearly demonstrated that the Perkinsus sp. found in $R$. variegatus grouped with $P$. honshuensis originating from $R$. philippinarum in Japan (Fig. 2A) with bootstrap support values of $100 \%$ in both NJ and MP analyses and a posterior probability of $96 \%$ in Bayesian analyses. This clade was sister to the $P$. olseni, $P$. mediterraneus and $P$. marinus clades. $P$. honshuensis, $P$. olseni, $P$. mediterraneus and $P$. marinus formed a clade that had high support by NJ analysis $(100 \%)$ and moderate support $(76 \%)$ in MP analysis and was sister to the P. chesapeaki and $P$. beihaiensis clades. Monophyletic species clades were well supported (i.e. $>85 \%$ ) in all analyses (Fig. 2A). In NJ, MP and Baysian phylogenetic analyses, the NTS region sequences from the $R$. variegatus Perkinsus sp. obtained for this study grouped with the NTS sequences determined for the $P$. honshuensis type strain, in a clade with $100 \%$ support in NJ, MP and Baysian analyses. This clade was a sister to $P$. olseni NTS from Asia, Europe and Australia with a high support in the NJ and MP analyses (i.e. 100\%) (Fig. 2B).

\section{DISCUSSION}

This study first identified Perkinsus sp. infections in the variegated carpet shell clam $R$. variegatus in Jeju Island, off the south coast of South Korea. $R$. variegatus occurs offshore in the Indo-Pacific, often in rocky environments rather than in the sandy environments which are preferred by its congener, the Manila clam (Ota \& Tokeshi 2000). On Jeju Island, Manila clams are typically found in sand or on sand-mud shores, whereas $R$. variegatus is found in a shallow layer of sand sediment below the gravel surface on pebble beaches. The variegated carpet shell clams analyzed in this study were also collected from a rocky, gravel beach. As Table 1 shows, the infection intensities are very light, such that, on the whole, only limited pathological signs were observed in histology (Fig. 1). 


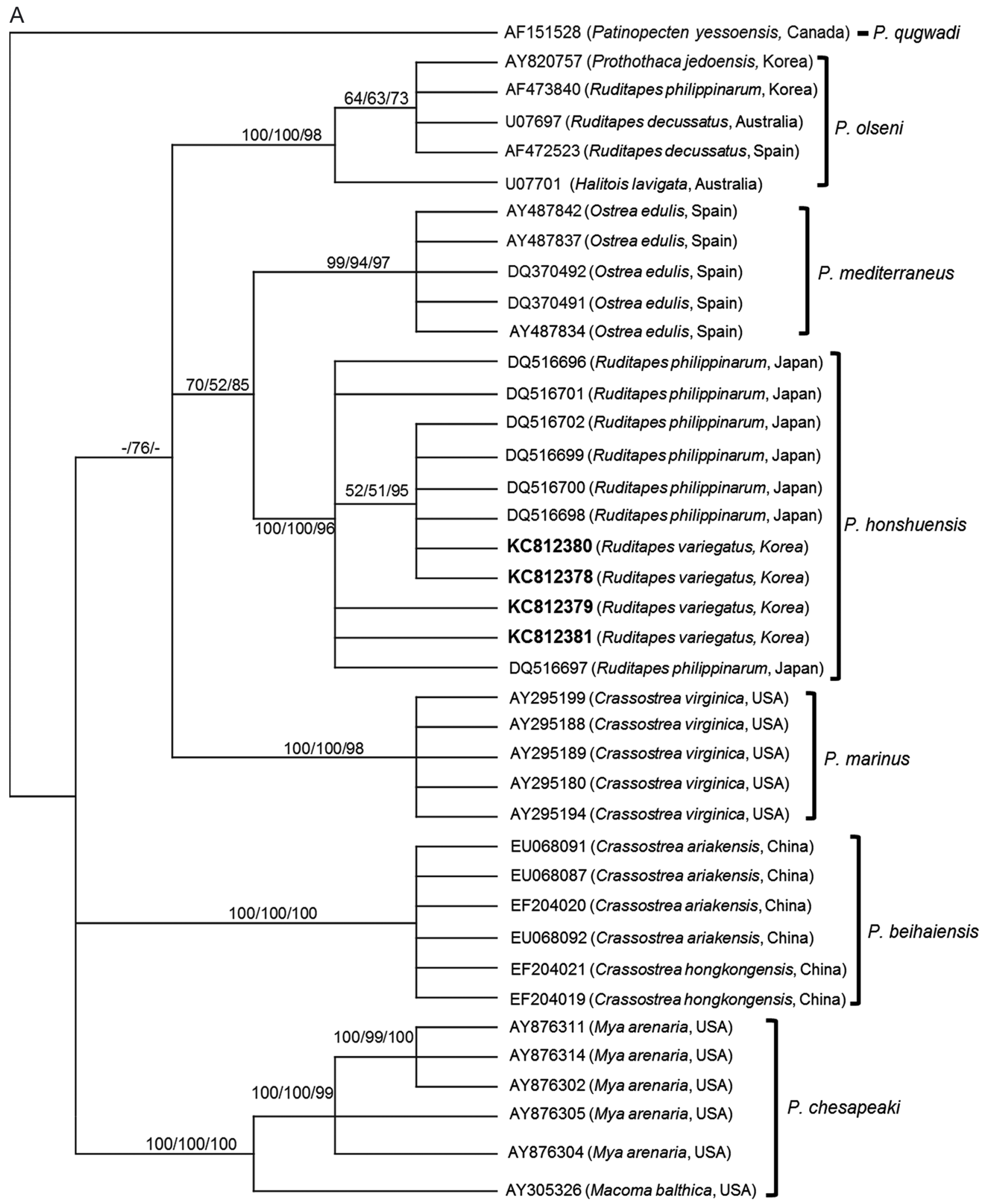

Fig. 2. Neighbor-joining (NJ) tree generated based on the (A) ITS and (B) NTS region sequences of Perkinsus spp. Bootstrap values $>50 \%$ are shown on branches; first value is from NJ analysis, second value is from maximum parsimony analysis, and the third value is the posterior probability resulting from Bayesian analyses. Bold letters indicate the sequences determined for this study

(Fig. 2 continued on next page) 
B

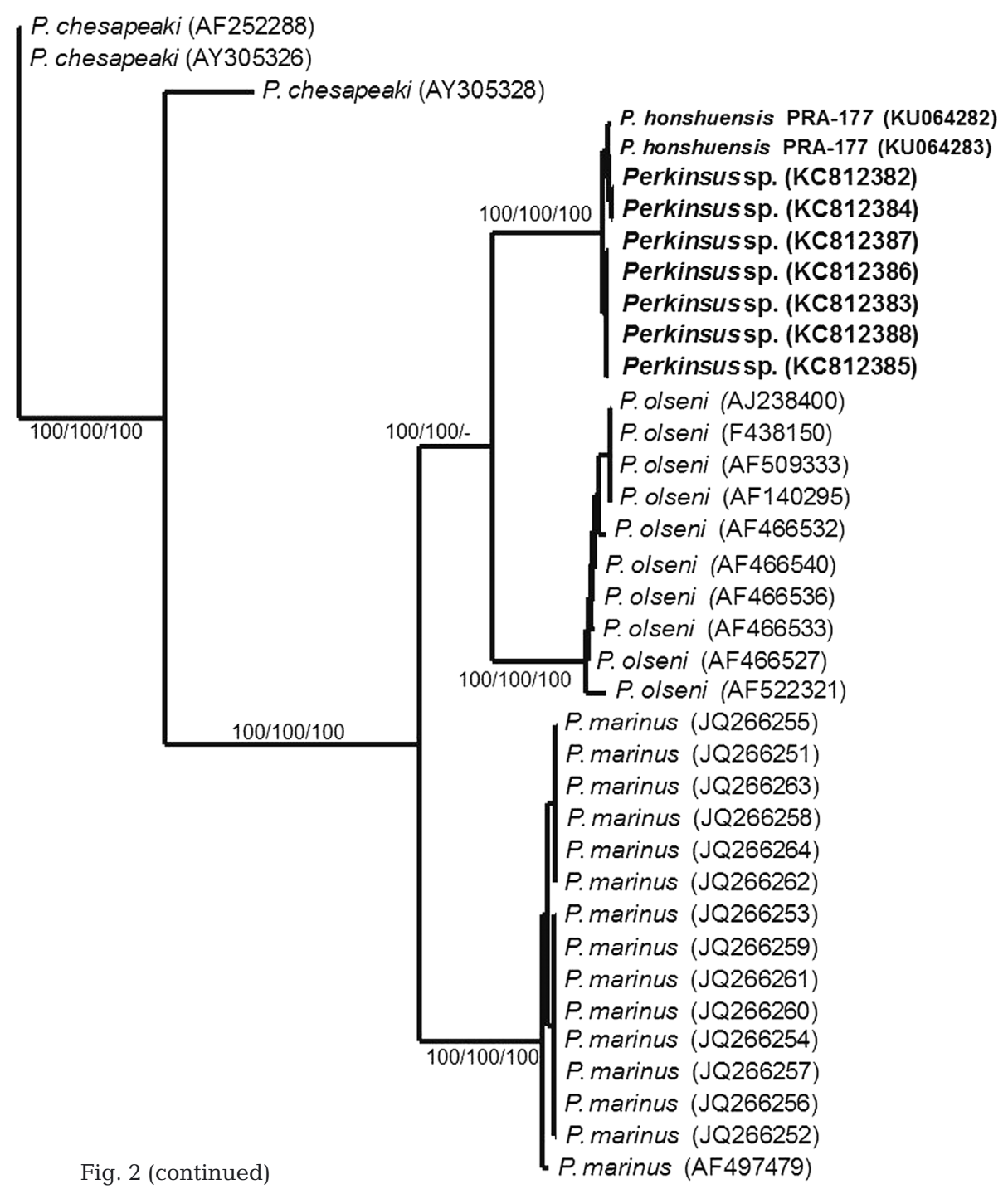

Dungan \& Reece (2006) established 4 in vitro cultures of Perkinsus sp. from Japanese Manila clams and obtained partial sequences of the large subunit rRNA (LSU) and actin genes and the complete sequence of the ITS region for these Perkinsus sp. isolates. The sequence analysis indicated that 1 isolate (Mie-3g) was distinct from the other 3 isolates (Mie$4 \mathrm{~g}$, Mie-5mg and Mie-13v), suggesting a new species that was described as $P$. honshuensis (Dungan \& Reece 2006). Although P. honshuensis has been associated with Manila clams of numerous Japanese populations and locations (Takahashi et al. 2009, Umeda \& Yoshinaga 2012), it has not previously been detected beyond Japanese waters.

The sequences of 4 Perkinsus sp. ITS regions obtained from $R$. variagatus showed $98.9-99.8 \%$ similarity to the ITS region sequences of $P$. honshuensis reported from $R$. philippinarum in Japan. The NTS region sequences amplified from $R$. variegatus also demonstrated $98.5-99.5 \%$ similarity to the NTS region sequences of the $P$. honshuensis type strain from this study. Phylogenetic analyses based on the ITS and NTS region sequences also revealed that the Perkinsus-like organisms from variegated carpet shell clams were distinctly grouped into a strongly supported clade with $P$. honshuensis, which is distinct from $P$. olseni reported from Korea, as well as from other Perkinsus spp. (Fig. 2). Accordingly, we conclude from our results that the host and geographic ranges for $P$. honshuensis now extend to include $R$. variegatus clams of Jeju Island, Korea.

It is interesting to note that typical pathological signs of Perkinsus sp. infections were very rare during microscopic examination of $R$. variegatus clams infected with $P$. honshuensis. Perkinsus sp. infections typically induce host responses such as hemocyte 
infiltration, necrosis and encapsulation. In host tissues, clusters of trophozoites are often observed surrounded by a capsule, as observed in the connective tissues of $R$. variegatus digestive gland tubules (Fig. 1). However, lesions with a massive hemocyte infiltration and tissue necrosis in the host tissue were not seen in these $P$. honshuensis-infected clams.

Dungan \& Reece (2006) reported the histopathologic features of $P$. honshuensis in Japanese Manila clams, where encapsulated $P$. honshuensis trophozoites were primarily found in the connective tissues. However, the pathologies observed in P. honshuensis-infected clams are not clearly distinct from those observed in hosts infected with other Perkinsus species. In addition, several recent studies on $P$. honshuensis-infected Manila clams in Japan revealed that most clams were co-infected with $P$. olseni (Takahashi et al. 2009, Umeda \& Yoshinaga 2012). Therefore, the particular impact of $P$. honshuensis on the health of clam hosts is unclear, and further studies will be needed to establish whether P. olseni and $P$. honshuensis demonstrate different levels of virulence and/or different pathologies.

Acknowledgements. The authors thank the staff of the Shellfish Aquaculture and Research Laboratory at Jeju National University and Ms. Gail Scott at the Virginia Institute of Marine Science (VIMS) for the laboratory work. We also express our gratitude to the 2 anonymous reviewers for the time they spent improving the standard of this article. This study was supported by a research fund from the Basic Science Research Program through the National Research Foundation of Korea (NRF), funded by the Ministry of Education, Science and Technology (grant number 2013R1A2A 2A01006529). This study was also supported by a project from the Ministry of Oceans and Fisheries of Korea: 'Longterm change of structure and function in marine ecosystems of Korea'. This is VIMS contribution \#3598.

\section{LITERATURE CITED}

Arzul I, Chollet B, Michel J, Robert M and others (2012) One Perkinsus species may hide another: characterization of Perkinsus species present in clam production areas of France. Parasitology 139:1757-1771

Choi KS, Wilson EA, Lewis DH, Powell EN, Ray SM (1989) The energetic cost of Perkinsus marinus parasitism in oysters: quantification of the thioglycollate method. J Shellfish Res 8:125-131

da Silva PM, Scardua MP, Vianna RT, Mendonça RC and

Editorial responsibility: Stephen Feist,

Weymouth, UK others (2014) Two Perkinsus spp. infect Crassostrea gasar oysters from cultured and wild populations of the Rio São Francisco estuary, Sergipe, northeastern Brazil. J Invertebr Pathol 119:62-71

> Dungan CF, Reece KS (2006) In vitro propagation of two Perkinsus spp. parasites from Japanese Manila clams Venerupis philippinarum and description of Perkinsus honshuensis n. sp. J Eukaryot Microbiol 53:316-326

> Katoh K, Standley DM (2013) MAFFT multiple sequence alignment software version 7: improvements in performance and usability. Mol Biol Evol 30:772-780

Ngo TTT, Choi KS (2004) Seasonal changes of Perkinsus and Cercaria infection in the Manila clam Ruditapes philippinarum from Jeju, Korea. Aquaculture 239: $57-68$

Ota N, Tokeshi M (2000) Population analysis of Ruditapes variegatus (Sowerby) (Bivalvia: Veneridae) on an intertidal boulder shore. Venus 59:29-36

Park KI, Choi KS (2001) Spatial distribution and infection intensity of the protozoan parasite Perkinsus sp. in the Manila clam Ruditapes philippinarum in Korea. Aquaculture 203:9-22

Park KI, Park JK, Lee J, Choi KS (2005) Use of molecular markers for species identification of Korean Perkinsus sp. isolated from Manila clams Ruditapes philippinarum. Dis Aquat Org 66:255-263

Park KI, Ngo TTT, Choi SD, Cho M, Choi KS (2006) Occurrence of Perkinsus olseni in the Venus clam Protothaca jedoensis in Korean waters. J Invertebr Pathol 93:81-87

Ray SM (1966) A review of the culture method for detecting Dermocystidium marinus, with suggested modifications and precautions. Proc Natl Shellfish Assoc 54:55-69

Ronquist F, Teslenko M, van der Mark P, Ayres DL and others (2012) MrBayes 3.2: efficient Baysian phylogenetic inference and model choice across a large model space. Syst Biol 61:539-542

Swofford DL (2002) PAUP* 4.0. Phylogenetic analysis using Parsimony (and other methods). Sinauer Associates, Sunderland, MA

Takahashi M, Yoshinaga T, Waki T, Shimokawa J, Ogawa K (2009) Development of a PCR-RFLP method for differentiation of Perkinsus olseni and P. honshuensis in the Manila clam Ruditapes philippinarum. Fish Pathol 44: 185-188

- Tamura K, Peterson D, Peterson N, Stecher G, Nei M, Kumar S (2011) MEGA5: molecular evolutionary genetics analysis using maximum likelihood, evolutionary distance, and maximum parsimony methods. Mol Biol Evol 28: 2731-2739

Umeda K, Yoshinaga T (2012) Development of real-time PCR assays for discrimination and quantification of two Perkinsus spp. in the Manila clam Ruditapes philippinarum. Dis Aquat Org 99:215-225

> Villalba A, Reece KS, Ordás MC, Casas SM, Figueras A (2004) Perkinsosis in molluscs: a review. Aquat Living Resour 17:411-432

Submitted: February 22, 2016; Accepted: September 12, 2016 Proofs received from author(s): November 6, 2016 